\title{
Revolution by stealth: the impact of learning development on democratising intelligence through constructive approaches to student support
}

\author{
Dr Stella Cottrell \\ University of Leeds, UK
}

\begin{abstract}
Learning development has played a key role in shaping learning and teaching in higher education over the last few decades. In the face of increasing student numbers, academic skills tutors have extended their roles such that, as well as supporting students to develop their individual skills, they now also contribute to areas such as curriculum development, staff training, and learning and teaching strategy. Where, initially, institutions offered support only for a small number of 'mechanical' study skills, there is greater recognition of the wide range of skills, habits, qualities and understandings that are required for students to perform at their best. This has been accompanied by more holistic approaches to students and their learning. An emergent property of such changes has been the 'democratising' of intelligence in higher education: we now have much greater appreciation for the role of educational 'inputs' on student performance and the effects of 'nurture' on what students can achieve. This raises challenges about what Higher Education Institutions should address through learning development into the future.
\end{abstract}

Keywords: learning development; student support; student performance; digital student; student engagement; study skills; skills framework.

\section{Introduction}

When an organisation celebrates its tenth anniversary and has a large and growing membership, it feels as if a notable milestone has been reached. Often, this is an indicator that a concept has come of age or, at least, that new ways of thinking are becoming established in the collective psyche. 2013 marks the tenth anniversary for the formal 
organisation of learning development through ALDinHE. That is no mean feat in itself, and a tribute to the efforts not just of volunteers, but of pioneers and innovators in terrains that, 30-40 years ago, had been generally inhospitable and frequently impenetrable. Looking back over that longer time span, this anniversary for ALDinHE can be regarded as one important step in a larger movement focused on a fundamental repositioning of learning and teaching within higher education (HE).

I was asked to speak at the anniversary conference about learning development to date, and to look ahead to potential future directions. Here, I will outline just some of the many changes that have taken place over the last few decades which formed the backdrop and context for the introduction and evolution of learning development within higher education. In that time, learning development has made a significant difference to the lives of many students and helped to shape our thinking about student achievement. In particular, it has helped us to appreciate that those who have under-achieved in the past can be supported to achieve well at later stages of their education. This owes, in part, to daily practice in the field, but also to research in other fields. I will consider some current trends and what these might mean for those working in higher education and learning development in the future. As a historian, the latter task feels highly unnatural - and as I am still awaiting the arrival of the life of ease and leisure promised by yesteryear's TV programme Tomorrow's World, I wouldn't ascribe a high level of confidence to any predictions of the future, including my own. However, I hope that these do provide some food for thought about the kinds of issues that we might need to address as learning developers of the future.

\section{Context}

'Learning development', as a concept within higher education, arose within the particular context of sharply rising numbers. In 1970, 51,189 students gained first degrees in the UK. This was an elite group, although the numbers in higher education were already many times greater than they had been at the start of the century. By 1990, the number of those graduating each year had risen only as far as 77, 163 (Bolton, 2012), but with increasing numbers of entrants, this was already perceived as a major shift in higher education. Patrick Ainley's Degrees of Difference (1994) attests to the magnitude of the changes as experienced at the beginning of the decade of 1990s: 'In the last few years there has been a sea change in higher education. Student numbers have expanded overwhelmingly and 
the language of competition, privatization and the market has now arrived on campus, and no one knows quite what will happen next' (Ainley, 1994, p.1). Yet, in retrospect, the change had barely begun. By 2000 , with additional growth and the inclusion of graduates from former polytechnics, numbers of graduates had risen to 243,256 students, and by 2011 to over 350,000 (Bolton, 2012).

The challenges posed by larger numbers were not simply those of class sizes and accommodation. There was a growing sense that entrants were, at best, more diverse and, at worst, not of the same calibre as those of the past. In 2003, an article was published in the Times Higher Education entitled: 'Entry grades are getting worse, so we've got to get better'. A poll of 500 UK academics found that $67 \%$ felt that students were leaving school less prepared for higher education, 58\% felt that easier university entry 'encouraged dumbing down', and 76\% felt that they had needed to adapt their teaching in response to increasing student diversity (Jobbins and Leon, 2003).

Growing numbers of participants in higher education challenged the concept of an education for the elite by the elite. Thus, it was not surprising to see debate, such as was presented by Gombrich (2000), Furedi (2004) and others, about the 'dumbing down' of higher education and the threat to a purer form of intellectual 'truth'. This wasn't restricted to higher education. The challenge was felt in related sectors such as museums, where the politics of wider access to education, staunchly defended by Ellis (2002) and Barr (2005), was seen by others as a threat to scholarship (Appleton, 2001). The division of opinion about the threat to intellectual life sometimes aligned with left/right politics but, as Barr pointed out, not necessarily so.

\section{Sink or swim}

To some extent, the lament about rising numbers and loss of a golden age of intellectual life was a simple reflection of fundamental and understandable reactions to such things as change itself, loss of the familiar, increased workload, and competing demands on time. For these reasons, some kickback could have been expected, irrespective of whether or not staff were in favour of widening access for its own sake. As resources didn't rise in line with growth in student numbers, self-preservation may have influenced perceptions. Moreover, the very concept of widening access was a threat to some academics' sense of 
identity: traditionally, the academic was regarded as part of a relatively small elite, generally assumed to be more intelligent. With larger numbers participating in higher education as teachers and as students, relatively less kudos attached to the role of the academic. This implied that intelligence was more broadly distributed than was believed. If this were not the case, and if standards were to be maintained, then many new entrants would fail. It was widely believed that increased access must mean either widespread student failure or an erosion of standards.

The prevailing assumption wasn't simply that students would arrive 'oven-ready' for higher education, but that they should. The culture was one of 'sink or swim': those with inherent ability would survive without orientation, direction, explanation, expert teaching, feedback, guidance or support. The rest didn't have the right to a place. Indeed, it was a matter of pride to be associated with a course with a high drop-out rate, this being taken to signify its level of difficulty. When student support was developing in the 1980s and 1990s, there was a grudging acceptance that a certain amount of catch-up on study skills might be acceptable for adults who might have become 'rusty', but many academics argued that for other students, any support was tantamount to spoon-feeding. The same view was held about accepting students who hadn't gained all their A levels in a single year. It was rarely long before discussions about struggling students reverted to references to ability, aptitude, 'IQ', 'bell curves' and even 'will power': these provided a rationale for not providing support. In The Bell Curve (1994), Herrnstein and Murray appeared to have demonstrated that IQ wasn't amenable to inputs from education and training. As most people didn't know their own IQ, it was broadly understood that individuals who did well in life had high IQs and others did not. As a low IQ was assumed to be (largely) inherent, such students who found their way into HE were doomed to ultimate failure and so there wasn't much point in Higher Education Institutions (HEIs) doing anything about it.

For nascent learning development units, there was a steep mountain to climb, not just conceptually but also in terms of systems, infrastructure, expertise, capacity and resources. It was apparent that learning development, if it was to be meaningful for students and staff, couldn't just chip away at the edges. Fundamental and large-scale change would be needed, involving 'whole institution' and 'whole student' approaches (Cottrell, 2001). Today, there is much greater investment in learning development - not just in terms of larger teams dedicated to developing students' academic skills, but also in terms of broader infrastructure. Many of the elements that early learning developers 
lobbied for are often now routinely established in HEls. It may seem unconceivable that there could once have been powerful objections to many of the practices that would be taken for granted today. These include such factors as teaching being taken seriously as part of job descriptions, with associated training and reward; leadership and management of the area such as through designated staff up to the highest levels of senior management, and specialist departments to spearhead pedagogic developments. It is now expected that students would receive clear guidance about such matters as learning outcomes, assessment criteria and feedback, as well as structured learning activities between taught sessions and direction on how to make creative use of taught time rather than regurgitate their lecture notes. Formative assessment is now used as a matter of course. The development of academic thinking and other study skills are, increasingly, being integrated into the curriculum. There is a plethora of materials for both students and staff to support study, learning and teaching. Most HEls provide additional support opportunities to help students to understand concepts that prove problematic. With the advent of league tables and student satisfaction surveys, there is growing interest in ensuring that all students are helped to improve their performance - and can recognise this for themselves. Many courses provide structured approaches to helping students to reflect upon how they learn and how to improve. From such a list, which is far from exhaustive, we can see how far the sector has travelled.

It is curious, though, how little prominence is still given through HEls' websites to provision that is available to students for improving their learning. This is especially so, since changes to fees and funding mean that students have a much greater vested interest in this and because support to improve students' performance can create real 'value-added'. Rather, such support is often hidden away, as if to admit that a need for it would reflect poorly on an HEl's intake. As it is a specialist area, and hard to get right both in terms of delivery and timing, study skills provision hasn't always been well received by students. It can be tempting to 'disappear' study skills behind other activities such as academic writing (Wingate, 2006) which appear more palatable, rather like concealing children's vegetables in mashed potato. Whilst there are all kinds of advantages to embedding support within curriculum delivery, it is rather more problematic to reduce a broad range of study skills down to just one area of skills, such as writing-related skills. It seems we still have some way to go, as a sector, in getting study skills provision right, taking pride in that, and giving it a higher profile. Until we are in a position to do this, and have confidence in our offer, it is likely to remain difficult to persuade students that study skills are a good thing. 


\section{Improving performance}

One reason why HEls are, perhaps, too coy about learning support is that study skills provision is often assumed to be solely for those from 'widening participation' backgrounds or only for those who are struggling. Support is sometimes described in negative terms, as if it automatically 'pathologises' students as 'needy' (Haggis, 2006). However, this may be because there hasn't been as much interest in recording the support offered to other kinds of student. Certainly, learning development was founded upon the core concept that everyone could improve performance, including gifted students and staff. In practice, students of all backgrounds make use of study skills resources, even at doctoral level at the most elite universities.

In the mid-1980s, I taught adult returners on pre-Access courses run by the Workers Education Association (WEA) in Oxford, on courses specially designed to develop skills, habits, and confidence through the way we worked with subject material. However, I also taught final year history undergraduates at Oxford University, at Somerville College, for an exam paper designed to draw together their understandings of historical methods and themes. I knew from discussions with my own peer group when I was a student that many students struggled with this paper. When teaching it, I found that students' difficulties arose from a multitude of misunderstandings about what was expected of them, as well as ineffective study habits. Some were using strategies that had worked at school without adapting these to the requirements of the course and context. Students described a variety of mechanisms they had adopted to help them cope, from excessive learning by rote, 'borrowing' other people's work and deciding tutors were wrong if their marks were low, through to alcoholism, eating disorders and self-harming. Although there were differences in the level at which the study skills issues were pitched, and I didn't use the term 'study skills', there was much common ground in what I covered with both sets of students. This included such themes as being more organised for study, reading critically, building a reasoned argument, synthesising material, drawing links across different kinds of subject material, organising their thoughts and structuring their writing, listening when others were talking, and giving critical feedback. In recent years, I know of others who have used study skills materials with students at Oxford, both undergraduate and postgraduate; Hill et al. (2010) have referred to learning development at Oriel College (2008). The University of Cambridge's (2013) website has a webpage headed: 'Support: Looking after our students that tells students not to worry if they 'need a bit of extra support while at the University". 
Even back in the 1950s at Harvard, when researching an elite group of students, Perry (1959) found that students turned up in unexpectedly large numbers when sessions in effective reading skills were offered. Students on all kinds of courses, at all levels, can improve their performance through changing their study strategies, habits and beliefs. In other words, study skills provision is not just about widening participation or weaker students.

Anxiety about study and doubts about personal capability are also found amongst different kinds of students, and not just those who are more obviously struggling. The access students, without a history of academic success, often believed they were 'not clever', as did many of the students I taught at the University of East London. However, so too did many of the Oxford college students. Despite their previous history of educational success, they often lacked confidence in their intelligence. This was especially the case if they had been closely tutored at home or at school or if they had been 'best in class' when at school but were no longer so once at university. Rather than recognising that the latter was a logical and expected outcome of being at a selective university, they internalised this as a failure of their own intelligence. It was noticeable that students' self-confidence was more brittle than it appeared, and often crumbled very quickly if they didn't do as well as they expected. The debate about 'IQ' had seeped into the mentality such that it blocked students from keeping occasional academic setbacks in perspective and identifying strategies that would help them to do better.

Fortunately, it has become more widely appreciated that IQ isn't just about inherent ability and so can be manipulated, although when and to what extent is still being debated. It is some time since research indicated that there was an independent effect of early years schooling on IQ, and that IQ was about more than just genes (Ceci, 1991; Winship and Korenman, 1997). However, it was only as recently as 2012 that researchers in Oslo identified that the effects of schooling as late as the mid teenage years could have an impact on IQ scores in later life (Brinch and Galloway, 2012). It is harder, as yet, to establish that 'IQ' can be further developed beyond the mid-teens and in adults. However, research on cognitive development in older adults does suggest that 'the potential for positive change, or plasticity, is maintained in adult cognition' and, interestingly, that this is sensitive to lifestyle and physical activity (Hertzog et al., 2008, p.1). That, in turn, suggests that the brains of adults between mid-teen and senior citizenship are likely to have similar 'plasticity' and be susceptible to educational inputs that improve learning. 
This was, indeed, our experience when we set up the Learning Development at UEL in 1991: even relatively small amounts of support had significant impacts on student achievement. It was evident from students' life and educational histories that there were a great many reasons other than IQ that could account for underachievement. Poor experiences of school, untimely illness, bereavement, pregnancy, peer hostility to learning, limited access to books, taking a job to support the family rather than doing homework, bullying, truancy, racism, disability, position in the family and myriad other factors (often experienced as multiple barriers) created blocks to academic success. The barriers that students encountered reflected inequalities in gender, age, disability, ethnicity and social class, and were generally also reflected in the performance of their schools and the quality of life in their neighbourhoods. The impacts of such barriers have been well documented (Swain et al., 1993; Bird, 1996; HEFCE, 1997; Bamber and Tett, 2001; Reay et al., 2002; National Audit Office, 2002; Leathwood and O'Connell, 2003). In the face of such factors, notions of inherent ability as the key rationale for academic achievement became more problematic. It was evident that students' performance could be improved, and to a significant degree, through addressing these issues and through students gaining a better understanding of what they needed to do in order to achieve well.

\section{Democratising intelligence}

The democratising of intelligence is, perhaps, the greatest legacy of the twentieth century, although the task isn't quite accomplished yet. This owes much to the work of educationalists such as Bruner (1966; 1975) and Vygotsky (1988), and to work undertaken in statutory and further education. It has taken us somewhat longer in higher education. For example, even if there are questions raised in the academic world about the empirical evidence to support theories of multiple intelligence (Gardner, 1993), there is at least much more widespread everyday acknowledgement now that people who have not excelled in a particular area can achieve well in others. We are much more aware of the differential roles of 'nature' and 'nurture' on individual achievement. We also know more about the impact of experience on brain functioning, including the development of domain specialisation. It is interesting to speculate on whether this might influence the work and thinking of learning developers in the future. Research already suggests that domain specialisation in the brain is a result of the activities that people undertake (or 'nurture'), not the cause of it ('nature'): the kind of learning experiences to which people are exposed 
shapes their brain. Musical training, at least in childhood, is associated with structural brain changes in motor and auditory areas and on related behaviours (Hyde et al., 2009). Both exercise and musical training appear to have broader impacts in areas such as 'auditory fitness', that then impact on a wide range of behaviours and capacities to learn (Kraus and Chandrasekaran, 2010). Trained musicians are better able to identify sound patterns in new languages (Wong and Perrachione, 2007), track for sound regularities and irregularities in the environment (Winkler et al., 2009), and have greater sensitivity to linguistic pitch contours (Kraus and Chandrasekaran, 2010). They have better second language acquisition (Strait et al., 2013) but also better vocabulary in their native tongue (Foregeard et al., 2008), as well as enhanced reading abilities (Overy, 2003; Tallal and Gaab, 2006) and even perception of emotion in speech (Strait et al., 2009). Although the benefits of music training appear greatest when training starts in early childhood, the impact of practice effects on neuroplasticity suggest that there could be cognitive benefits to those who start training and practice music when they are older (Musacchia et al., 2007; Parbery-Clark et al., 2009; Strait et al., 2009).

Furthermore, developing skills in one area may facilitate or inhibit learning in other areas. Research into London cab drivers suggests that the particular skills in the representation of spatial relations, gained through years of navigating a large city and using a rules-bound approach, are accompanied by a greater volume of grey matter volume in the posterior hippocampus but reduced grey matter in other parts of the hippocampus (Maguire et al., 2006, p.1099). Their skill in one area appeared to lead to 'a compromised ability to acquire or retrieve new visuo-spatial information'. There can be a cost to what we learn. This means that the way that the curriculum is structured, such as whether it is more broadbased or more specialist, could be having unrecognised impacts on domain development, for better or ill. On the other hand, bio-cultural research further suggests that, from early adulthood onwards, 'cognitive pragmatics' come into play that enable adults to make more effective use of context and experience. Baltes and Singer (2001, p.59) argue that 'professional expertise, artistic competence, social-emotional intelligence and wisdom are examples of late-life potentials in the cognitive pragmatics'. Depending on the outcome of further research in areas such as neuropsychology and bio-cultural sciences, learning development of the future may be directed to structuring student experiences such that these optimise the development of particular domains, using curricula and teaching methods relevant to the age, interests and ambitions of the students. Perhaps, alongside 
battles on genetic engineering, we may be drawing lines in the sand on 'cognitive engineering'.

\section{The digital generation}

If domain development is affected by practice effects, this raises questions about a whole host of other experiences that could be shaping students' aptitudes for learning under different conditions. For example, we hear much about 'the digital student' as if students were extensions of the technology they use. Some, such as Prensky (2001) and Oblinger et al. (2005), have gone so far as to argue that pedagogies should shift to accommodate the learning styles, behaviours and changed expectations of 'digital natives'. Prensky (2001, p.4) recommended that academics needed to devise ways of 'going faster, less step-by step, more in parallel, with more random access'. Others, though, have challenged the empirical evidence for changed learning styles and behaviours amongst the 'digital' generation (Bennett et al., 2008) - or even that it makes as much use of web technologies as is assumed. Although students may be familiar with a wider range of technologies and adept at using them in particular contexts, there hasn't been automatic and widespread transfer of such usage to enhance their learning. Research findings from the US, UK and Australasia have challenged the assumption that students' internet skills are as prevalent as was believed (Palfrey and Gasser, 2008; Kennedy et al., 2008; Jones and Cross, 2009; Hargittai, 2010) and that students are 'net-savvy' (Lorenzo and Dziuban, 2006; Oblinger and Hawkins, 2006.) JISC reported in 2008 (Ipsos MORI on behalf of JISC, 2008) that the 'internet generation' - that is, those born after 1993 - was not generally very skilled at online research beyond the use of Wikipedia, and that students made little use of their everyday technologies in their studies unless prompted to do so. Whilst students' use of technologies is, as yet, too heterogeneous to merit the radical overhaul of pedagogies Prensky advocates, the increased use of technologies, not least by new generations of academic staff, is likely to mean that methods of teaching will look very different in 10-20 years' time. This is likely to have consequences for the kind of orientation to study that our students will need, as well as what we provide to develop skills which support their learning.

Meanwhile, the net impact of students' recurrent use of technologies may well affect their neural development in ways that are not yet clear. The daily recurrence of search 
activities, in rapid, open-ended, associative, non-linear pathways, may lead to different kinds of neural development than that which arises from the sequential, logical, analytical thinking more typical of $A$ level and for HE courses. The way we interact with information for everyday and, increasingly, for academic purposes, using phones and tablets and social networking tools, gives a sense of endless plurality, collaboration and flexible interconnectedness. It is not unreasonable to assume that this will impact on how our brains develop and, therefore, on how we think. It is also possible that this may come at a cost to other kinds of thinking processes: it may mean that, as for cab drivers, students develop new areas of strength but also some potential restrictions in their abilities to acquire, recall, make sense of, and apply new information. The most obvious, though as yet unestablished outcomes, would be that when students first enter higher education, they would find it more problematic to maintain logical, sequential thinking or to work in a sustained manner over long periods in order to master complex problems. This may raise some interesting dilemmas for learning developers about how best to play to students' learning strengths, and when and how to nurture thinking skills and learning behaviours that may be less developed.

\section{Study skills - here and now}

That is for the future, but what about now? Whilst it is an especially volatile time in higher education, and therefore hard to predict what may rise to the top of the learning development agenda, it is probable that many HEls will be even more at pains to help their students to achieve well, gain good degree classifications and improve their own league table positions. Where they are competing for students, or where students are self-funding, HEls will be keen to demonstrate to students that they have done everything they can to help them to achieve their potential. This raises the importance of manifestly good teaching and of demonstrating 'value-added'.

The likelihood is that we will see an increased emphasis on more carefully constructed learning experiences. We have already seen significant movement away from the concept of teaching as 'delivery' of information to students and greater, although not universal, recognition that the issue is no longer one of limited access to information. We are still establishing expertise in helping students to make sense of information, and in understanding what can be done when they don't - apart from failing them. We are still 
prone to slippage in this area. As a sector, whenever new media appear, we have a tendency to revert to using these as new means for providing information, rather than as tools for developing cognitive processes and promoting better understanding.

Nonetheless, there are exciting developments in collaborative online learning, creative use of meaningful student research projects, use of hand held voting devices to encourage interactivity and discussion in class, and increased use of structured reflection, all of which place the emphasis on students having greater agency in their own learning. For decades, there have been voices raised against the use of lectures simply for 'transmitting' information and arguments for using the time for meaningful discussion of the issues instead. The recent rebranding of that basic concept as the 'flipped classroom' is capturing the imagination of more lecturers. All of these create new learning experiences, providing fertile ground for learning developers to support both staff and students.

Just as changes in use of technology may have an impact on the kinds of thinking skills that HEls might need to develop within their students, so changes in the way we construct and deliver the curriculum will shape the pattern of skills and support that students will need if they are to perform well. Where the first academic skills tutors, or their equivalents, needed to focus almost exclusively on the 'mechanics' of study skills (such as making notes, organising information, preparing for exams), learning developers now address a much broader range of issues, working closely with academics or as academics themselves, and operating more strategically. They are also addressing a much broader range of skills.

One emergent feature of higher education in recent decades is an ever longer list of skills, attributes and qualities that we expect students to have as graduates (Cottrell, 2010). This is driven partly by the increased focus on employability and the desire to give graduates the edge in gaining good jobs. It is also the result of an increased awareness of how complex an activity it is to 'learn' and to develop independent learning of challenging material in a time bound, assessment-based context. We are much more conscious of the range of skills, behaviours, attitudes and personal qualities that can contribute to a student completing a course and achieving well. As a result, there are now long and often rather daunting lists of required skills either on institutional websites or specified as required outcomes for programmes. It takes particular sets of skills in students to be able to make sense of the ever growing demands that are made of them and to maintain confidence that 
they can deliver on these. Sometimes, these lists are so long that it must be a challenge for students simply to remember them.

Where previous study skills provision focused on mechanical skills for learning, students today generally need to develop skills in four overarching areas: cognitive, interpersonal, operational and intra-personal. In the student vernacular, these translate to academic skills, people skills, task-management skills and self-management skills, as outlined in the APT-S study skills framework (Cottrell, 2013). There are strong continuities in the kinds of cognitive skills required past and present, such as critical analysis, synthesis, information processing or use of memory and recall. These are not likely to go away as requirements, although we are now more aware that we can influence how these develop and are likely to change in the ways that we go about developing them. In the last twenty years, we have become increasingly aware of the importance of developing the other three skills areas and these are starting to become much more integrated into curricular and co-curricular arrangements. People skills, long demanded by employers, are now recognised as important to managing the academic environment, whether contributing in class, working with research participants, managing relationships with supervisors or taking part in collaborative online learning activities. Good task management skills help students to organise their studies, reducing the demands on personal tutors: skills in planning meaning they are more likely to hand in assignments on time; project management skills help them with research projects at college and are relevant to employment.

Perhaps the most interesting addition to the quartet of skills areas is that related to intrapersonal development, or 'self-management skills'. This is the latest to enter the arena and the one where we are likely to see capacity-building in future years. Although HEls have long wanted to see self-reliant students who can 'take responsibility for their own learning', the emotional demands of moving from dependent to independent modes of learning is only slowly being acknowledged. That this might fall to HEls themselves to address is an even more recent phenomenon. Further, despite Piaget's work (1975) on the 'disequilibration' that arises within the learning process, and the difficulties that students have in managing ambiguities that arise when they have to move away from familiar concepts (Cottrell, 2001), it is only recently that this has started to be addressed within the context of 'threshold concepts' for discipline-based knowledge. Whilst the notion of threshold concepts (Meyer and Land, 2006; Land et al., 2008) helps academics to make sense of students' difficulties with learning material within the discipline, there are also 
generic issues about the unsettling nature of higher level learning. These could be addressed either within a discipline or across disciplines. For students, what is most unsettling is that perceived fundamental 'truths' or 'facts' might be challenged at all. They are not, then, always sure how to hold ambiguity in ways that enable them to keep functioning well as students. We are also more aware, now, of the affective issues associated with starting in higher education, such as leaving home or juggling study with family responsibilities, and the impact these have on learning. At schools level and in higher education, we are seeing an increased interest in skills in self-management, clustered under headings such as resilience, mindfulness and emotional literacy. This is an area that is likely to grow.

\section{Conclusion}

There are opportunities for learning development to continue to play an important role in higher education, not just in supporting students, but also staff and whole institutions. The work of learning developers can play a key role in attracting students, preparing them at entry, ensuring they stay on to complete their courses and that they achieve well. Good support for learning, both integrated into course delivery and through additional opportunities for individuals, can help to raise student and institutional performance. Where social and psychological factors have predominance now, it may be that, in the longer term, we come to look more to areas such as neuroscience to help us to understand how our students are thinking and how we could support, if not 'engineer', their learning. If so, this might bring some profound changes to learning development of the future. As we become more aware of the role of 'nurture', or educational inputs, in shaping not just intelligence but even brain development, and as we gain greater recognition of the mediating role of intra-personal factors, then the scope and importance of learning development should increase. Hopefully, HEls will come to feel that this area is one that they should not 'hide away' and is, indeed, one that it is in their interests to promote.

\section{References}

Ainley, P. (1994) Degrees of difference: higher education in the 1990s. London: Lawrence and Wishart. 
Appleton, J. (2001) Museums for 'The People'. Conversations in print. London: Institute of Ideas.

Baltes, P.B. and Singer, T. (2001) 'Plasticity and the ageing mind: an exemplar of the biocultural orchestration of brain and behaviour', European Review, 9(1), pp. 59-76.

Bamber, J. and Tett, L. (2001) 'Ensuring integrative learning experiences for nontraditional students in higher education', Widening Participation and Lifelong Learning, 3(1), pp. 8-16.

Barr, J. (2005) 'Dumbing down intellectual culture: Frank Furedi, lifelong learning and museums', Museum and society, 3 (2), pp. 98-114 [Online]. Available at: http://www2.le.ac.uk/departments/museumstudies/museumsociety/documents/volu mes/barr.pdf (Accessed: 26 July 2013).

Bennett, S., Maton, K. and Kervin, L. (2008) 'The 'digital natives' debate: a critical review of the evidence', British Journal of Educational Technology, 39(5), pp., 775-786.

Bird, J. (1996) Black students and higher education: rhetorics and realities. Buckingham: SRHE and Open University Press.

Bolton, P. (2012) Education: historical statistics. Standard Note SN/SG/4252. House of Commons Library.

Brinch, C.N. and Galloway, T.A. (2012) 'Schooling in adolescence raises IQ scores', Proceedings of the National Academy of Sciences of the United States of America, 109(2), pp. 425-430.

Bruner, J. (1966) Towards a theory of instruction. New York: W.W. Norton.

Bruner, J. (1975) 'The ontogenesis of speech acts', Journal of Child Language, 2(1), pp. 119. 
Ceci, S.J. (1991) 'How much does schooling influence general intelligence and its cognitive components? A reassessment of the evidence', Developmental Psychology, 27, pp. 703-722.

Chandrasekaran, B. and Kraus, N. (2010) 'The scalp-recorded brainstem response to speech: neural origins and plasticity', Psychophysiology, 47(2), pp. 236-246.

Cottrell, S.M. (2001) Teaching study skills and supporting learning. Basingstoke: Palgrave Macmillan.

Cottrell, S.M. (2010) Skills for success. Personal development planning and employability. $2^{\text {nd }}$ edn. Basingstoke: Palgrave Macmillan.

Cottrell, S.M. (2013) The study skills handbook. $4^{\text {th }}$ edn. Basingstoke: Palgrave Macmillan.

Ellis, L. (2002) 'The backlash to access', Engage, 11, pp. 40-2.

Forgeard, M., Winner, E., Norton, A. and Schlaug, G. (2008) 'Practicing a musical instrument in childhood is associated with enhanced verbal ability and nonverbal reasoning', PLoS ONE, 3(10), e3566.

Furedi, F. (2004) Where have all the intellectuals gone? Confronting twentieth century philistinism. London and New York: Continuum.

Gardner, H. (1993) Frames of mind: the theory of multiple intelligences. $2^{\text {nd }}$ edn. London: Fontana.

Gombrich, R.F. (2000) British higher education policy in the last twenty years: the murder of a profession. Lecture in Tokyo at the Graduate Institute of Policy Studies (GRIPS), 7 January. Available at:

http://www.atm.damtp.cam.ac.uk/mcintyre/papers/LHCE/uk-higher-education.html (Accessed: 14 July 2013). 
Haggis, T. (2006) 'Pedagogies for diversity: retaining critical challenge amidst fears of 'dumbing down', Studies in Higher Education, 31(5), pp. 521-535, Society for Research into Higher Education.

Hargittai, E. (2010) 'Digital Na(t)ives? Variation in internet skills and uses among members of the "Net Generation”, Sociological Inquiry, 80(1), pp. 92-113.

Herrnstein, R.J. and Murray, C. (1994) The bell curve: intelligence and class structure in American life. New York: Free Press.

Hertzog, C., Kramer, A.F., Wilson, R.S. and Lindenberger, U. (2008) 'Enrichment effects on adult cognitive development can the functional capacity of older adults be preserved and enhanced?', Psychological Science in the public interest, 9(1), pp. 165.

Higher Education Funding Council for England (1997) The participation of non-traditional students in higher education. Bristol: Higher Education Funding Council for England.

Hill, P., Tinker, K. and Catterall, S. (2010) 'From deficiency to development: the evolution of academic skills provision at one UK university', Journal of Learning Development in Higher Education, Issue 2 February, pp. 1-19.

Hyde, K.L., Lerch, J., Norton, A., Forgeard, M., Winner, E., Evans, A.C. and Schlaug, G. (2009) 'Musical training shapes structural brain development', The Journal of Neuroscience, 29(10), pp. 3019-3025.

Ipsos MORI on behalf of JISC (2008) Great expectations of ICT: how higher education institutions are measuring up. Available at: www.jisc.ac.uk/media/documents/publications/jiscgreatexpectationsfinalreportjune0 8.pdf (Accessed: 25 August 2013).

Jobbins, D. and Leon, P. (2003) 'Teaching poll: 'entry grades are worse, so we've got to get better", Times Higher Education, 23 May. 
Jones, C. and Cross, S. (2009) 'Is there a net generation coming to university?', 'In dreams begins responsibility': choice, evidence and change: ALT-C 2009. Manchester, UK 8-10 September.

Kennedy, G.E., Judd, T.S., Churchward, A., Gray, K. and Krause, K. (2008) 'First year students' experiences with technology: are they really digital natives?', Australasian Journal of Educational Technology, 24(1), pp. 108-122.

Kraus, N. and Chandrasekaran, B. (2010) 'Music training for the development of auditory skills', Nature Reviews Neuroscience, 11, pp. 599-605.

Land, R., Meyer, J.H.F. and Smith, J. (2008) Threshold concepts within the disciplines. Rotterdam: Sense Publications.

Leathwood, C. and O'Connell, P. (2003) 'It's a struggle': the construction of the 'new student' in higher education', Journal of Education Policy, 18(6), pp. 597-615.

Lorenzo, G. and Dziuban, C. (2006) 'Ensuring the Net generation is Net savvy', EDUCAUSE Learning Initiative Paper 2. Boulder, CO: EDUCAUSE. Available at: http://www.educause.edu/ir/library/pdf/ELI3006.pdf (Accessed: 15 August 2013).

Maguire, E.A., Woollett, K. and Spiers, H.J. (2006) 'London taxi drivers and bus drivers: a structural MRI and neuropsychological analysis', Hippocampus, 16(12), pp. 10911101.

Meyer, J.H.F. and Land, R. (eds.) (2006) Overcoming barriers to student understanding: threshold concepts and troublesome knowledge. Abingdon: Routledge.

Musacchia, G., Sams, M., Skoe, E. and Kraus, N. (2007) 'Musicians have enhanced subcortical auditory and audiovisual processing of speech and music', Proc. Natl Acad. Sci. USA, 104, pp. 15894-15898.

National Audit Office (2002) Widening participation in higher education in England. London: The Stationery Office. 
Oblinger, D., Oblinger, J.L. and Lippincott, J.K. (2005) 'Educating the Net Generation'. Brockport Bookshelf. Book 272. Available at:

http://digitalcommons.brockport.edu/bookshelf/272 (Accessed: 22 August 2013).

Oblinger, D.G. and Hawkins, B.L. (2006, March/April) 'The myth about student competency', Educause Review, 41(2), pp. 12-13.

Oriel College, University of Oxford (2008) LearnSmart: getting the most out of Oxford. Oxford: Oxford University.

Overy, K. (2003) 'From timing deficits to musical intervention', Ann. NY Acad. Sci, 999, pp. 497-505.

Palfrey, J. and Gasser, U. (2008) Born digital: understanding the first generation of digital natives. New York: Basic Books.

Parbery-Clark, A., Skoe, E. and Kraus, N. (2009) 'Musical experience limits the degradative effects of background noise on the neural processing of sound', Journal of Neuroscience, 29(45), pp. 14100-14107.

Perry, W.G. (1959) 'Students' uses and misuses of reading skills, A report to the faculty', Harvard Educational Review, 29, pp. 193-200.

Piaget, J. (1975) The development of thought: equilibration of cognitive structures. Oxford: Blackwell.

Prensky, M. (2001) 'Digital natives, digital immigrants part 1', On the Horizon, 9(5), pp. 1$6)$.

Reay, D., Balls, S. and David, M. (2002) "It's taking me a long time but I'll get there in the end': mature students on access courses and higher education choice', British Education Research Journal, 28(1), pp. 5-19. 
Strait, D.L., Kraus, N., Skoe, E. and Ashley, R. (2009) 'Musical experience and neural efficiency: effects of training on subcortical processing of vocal expressions of emotion', European Journal of Neuroscience, 29(3), pp. 661-668.

Strait, D.L., O'Connell, S., Parbery-Clark, A. and Kraus, N. (2013) 'Musicians' enhanced neural differentiation of speech sounds arises early in life: developmental evidence from ages 3 to 30', Cerebral Cortex, first published online 18 April 2013.

Swain, J., Finkelstein, V., French, S. and Oliver, M. (eds.) (1993) Disabling barriers enabling environments. London: Sage.

Tallal, P. and Gaab, N. (2006) 'Dynamic auditory processing, musical experience and language development', Trends in Neuroscience, 29(7), pp. 382-390.

University of Cambridge (2013) Support: looking after our students. Available at: http://www.study.cam.ac.uk/undergraduate/support/ (Accessed: 20 August 2013).

Vygotsky, L.S. (1988) 'The genesis of higher mental functions', in Richardson, K. and Sheldon, S. (eds.) Cognitive development to adolescence. Hove: Erlbaum, pp. 6179.

Wingate, U. (2006) 'Doing away with 'study skills', Teaching in Higher Education, 11(4), pp. 457-469.

Winkler, I., Denham, S.L. and Nelken, I. (2009) 'Modeling the auditory scene: predictive regularity representations and perceptual objects', Trends in Cognitive Sciences, 13(12), pp. 532-540.

Winship, C. and Korenman, S. (1997) 'Does Staying in School Make You Smarter?', in Devlin, B., Fienberg, S.E., Resnick, D.P. and Roeder, K. (eds.) Intelligence, genes, and success. Scientists respond to the bell curve. Springer: New York, pp. 215234.

Wong, P.C.M. and Perrachione, T.K. (2007) 'Learning pitch patterns in lexical identification by native English speaking adults', Appl. Psycholinguist, 28(4), pp. 565-585. 


\section{Author details}

Dr Stella Cottrell is Director for Lifelong Learning at the University of Leeds, Deputy Chair of Governors at Leeds College of Art, Chair of the Yorkshire and Humber Access to HE Committee, and a Trustee for OCNYHR. She was a co-founder of one of the earliest Learning Development departments in higher education, at UEL in 1991. She has been a lifelong advocate of improving student achievement through the way that learning opportunities are designed and supported. Her best known works are The Study Skills Handbook (Palgrave 2013, $4^{\text {th }}$ edn.), Teaching Study Skills and Supporting Learning (Palgrave, 2001) and other texts that support independent study in higher education. 